\title{
The Technical Quality of Wood of Scots Pine (Pinus sylvestris L.) of Diverse Genetic Origin †
}

\author{
Eliza Konofalska ${ }^{1}$, Paweł Kozakiewicz ${ }^{2}$, Włodzimierz Buraczyk ${ }^{3}$, Hubert Lachowicz ${ }^{4}$ \\ 1 Kielce Forest District, Hubalczyków 15, 25-668 Kielce; e-mail: konofalskaeliza@gmail.com \\ 2 Department of Wood Science and Wood Preservation, Institute of Wood Sciences and Furniture \\ Manufactoring, Warsaw University of Life Sciences; ul. Nowoursynowska 159, 02-776 Warszawa; e-mail: \\ pawel_kozakiewicz@sggw.pl \\ 3 Department of Forest Silviculture, Institute of Forest Sciences, Warsaw University of Life Sciences; \\ ul. Nowoursynowska 159, 02-776 Warszawa; e-mail: wburaczyk@wp.pl \\ 4 Department of Forest Utilization, Institute of Forest Sciences, Warsaw University of Life Sciences; \\ ul. Nowoursynowska 159, 02-776 Warszawa; e-mail: hubert_lachowicz@sggw.edu.pl \\ + Presented at the 1st International Electronic Conference on Forests, 15-30 November 2020; \\ Available online: https://sciforum.net/conference/IECF2020 \\ Published: 31 October 2020
}

\begin{abstract}
This work contains the preliminary results of research into the technical quality of wood from Scots pine trees of diverse genetic origin, grown on an experimental plot at the Forest Experimental Station in Rogów. These are the parent stands numbered 5 (Bory Tucholskie region $130 \mathrm{~m}$ a.s.l.), 7 (Lasy Napiwodzko-Ramuckie $145 \mathrm{~m}$ a.s.l.), 10 (Puszcza Piska $145 \mathrm{~m}$ a.s.l.), 12 (Puszcza Biała 95 m a.s.l.), 13 (Lasy Namysłowsko-Ostrzeszowskie $190 \mathrm{~m}$ a.s.l.), 15 (Puszcza Knyszyńska $165 \mathrm{~m}$ a.s.l.) and 16 (Bory Nowotarskie $590 \mathrm{~m}$ a.s.l.). The tested wood was obtained in 2018 from trees aged 52 years. The research material came from 100 trees in total. After felling, two logs approximately $0.5 \mathrm{~m}$ in length were cut from each tree. The height on the tree from which the material was taken ranged from breast height $(1.3 \mathrm{~m})$ to approximately $2.5 \mathrm{~m}$. Next, planks were cut from the logs in a north-south direction; these were precisely described, and then left to season. The work included the measurement and statistical analysis of one physical property; wood density $\left[\mathrm{kg} / \mathrm{m}^{3}\right]$, and of the following mechanical properties: compressive strength along the fibres; $\mathrm{Rc}_{12}$ [MPa]; static bending strength; $\mathrm{Rg}_{12}$ [MPa]; modulus of elasticity under static bending; $\mathrm{Eg}_{12}$ [MPa]; and indices of strength quality of the tested mechanical properties; JRc12; JRg $\operatorname{Rg}_{12} ; \mathrm{JEg}_{12}[\mathrm{~km}]$. Origin was shown to have a significant influence on wood density, compressive strength, static bending strength, and modulus of elasticity under static bending. The highest mean density was found for trees originating from stand $10\left(537 \mathrm{~kg} / \mathrm{m}^{3}\right)$. The highest values of compressive strength were obtained for trees originating from stands $5(45 \mathrm{MPa})$, and the highest static bending strength and modulus of elasticity under static bending were obtained for trees originating from stand 12 (102 and $9825 \mathrm{MPa}$ respectively).
\end{abstract}

Keywords: Pinus sylvestris L., wood density; mechanical properties; technical quality of wood

\section{Introduction}

Scots pine (Pinus sylvestris L.) has a range that covers the whole of Scandinavia, north-eastern areas of European Russia, and Siberia, extending eastward as far as the Sea of Okhotsk and the Sea of Japan. In Poland it is a dominant forest species, covering $66.5 \%$ of total forest area, according to figures for 1 January 2017 [1]. It is found from sea level to mountain peaks up to around $2700 \mathrm{~m}$ above sea level in the Caucasus [2]. In Poland it occurs mainly in lowland areas, reaching elevations of $700 \mathrm{~m}$ in the Carpathians, although individual trees are found up to $1100 \mathrm{~m}$ above sea level [3]. 
Pine wood is valued and widely used not only due to its availability, but also because of its physical and mechanical properties. Its technical properties depend, among other things, on its geographical origin. Paschalis [4] showed that the properties of pine wood deteriorate in a direction from north to south, while on the east-west axis there is no definite tendency. It is thus generally believed that pine wood from northern parts of Poland is superior, offering greater density and strength [5].

The technical quality of wood is affected by a number of factors. It depends mainly on geographical location, habitat type, and the quality of planting material [6]. The effects of habitat type were studied by Józefaciuk and Laurow [7], and later also by Krzysik [8]. Genetics, environment and human factors can determine the properties and structure of wood [9]. Wood quality may be influenced by genotype. The genome may exhibit phenotypic features and determine resistance to internal and external factors. It has been demonstrated, for example, that branch thickness is genetically conditioned [10, 11].

Scots pine (Pinus sylvestris L.) is a species with a very wide natural range. Because it grows in different climatic and soil conditions, it exhibits great variation as regards the morphology, yield and quality of its timber. The most important method enabling the evaluation of variability between and within populations of forest trees is comparative provenance experiments.

The goal of this work was to investigate selected physical and mechanical properties of the wood of Scots pine (Pinus sylvestris L.) with seven different genetic origins, grown on an experimental plot at the Forest Experimental Station in Rogów.

\section{Methods}

\subsection{Study site}

This work contains the preliminary results of research into the technical quality of wood from Scots pine trees of diverse genetic origin, grown on an experimental plot at the Forest Experimental Station in Rogów. The studied trees are offspring of seven parent populations of Scots pine growing in areas of fresh mixed forest type (LMśw). These are the parent stands numbered 5 (Lipowa, in the Bory Tucholskie region $130 \mathrm{~m}$ a.s.l.), 7 (Dłużek, Lasy Napiwodzko-Ramuckie $145 \mathrm{~m}$ a.s.l.), 10 (Ruciane, Puszcza Piska 145 m a.s.l.), 12 (Jegiel, Puszcza Biała m 95 a.s.l.), 13 (Rychtal, Lasy Namysłowsko-Ostrzeszowskie 190 m a.s.l.), 15 (Supraśl, Puszcza Knyszyńska 165 m a.s.l.) and 16 (Nowy Targ, Bory Nowotarskie 590 m a.s.l.).

The experimental site is located in central Poland, at an elevation of $160 \mathrm{~m}$ above sea level. Average annual precipitation is $595 \mathrm{~mm}$, and the average annual air temperature is $7.2^{\circ} \mathrm{C}$. All trees from the seven parent populations grow in a fresh mixed forest habitat, under identical growing conditions.

Forest habitat type is a basic unit in the system of classification of forest habitats. A single type includes forest areas with similar conditions in terms of soil fertility and humidity, climate, land form and geological structure. Areas assigned to the same forest habitat type have similar productive capacity and suitability for forest cultivation [1].

\subsection{Obtaining and preparing samples for analysis}

The tested wood was obtained in 2018 from trees aged 52 years. The research material came from 100 trees in total. After felling, two logs approximately $0.5 \mathrm{~m}$ in length were cut from each tree. The height on the tree from which the material was taken ranged from breast height $(1.3 \mathrm{~m})$ to approximately $2.5 \mathrm{~m}$. Next, planks were cut from the logs in a north-south direction; these were precisely described, and then left to season. Samples were then produced for particular types of tests in accordance with the relevant provisions of the Polish Standards PN-77/D-04227 [12].

\subsection{Determination of selected properties}

The work included the measurement and statistical analysis of one physical property, wood density $\left[\mathrm{kg} / \mathrm{m}^{3}\right]$ according to standard PN-77/D-04101 [13], and of the following mechanical 
properties: compressive strength along the fibres, $\mathrm{R}_{12}$ [MPa] according to standard PN-78/D-04102 [14]; static bending strength, $\operatorname{Rg}_{12}$ [MPa] according to standard PN-77/D-04103 [15]; modulus of elasticity under static bending, Eg 12 [MPa] according to standard PN-63/D-04117 [16]; and indices of strength quality of the tested mechanical properties, JRc12, JRg $\operatorname{R}_{12}, \mathrm{JEg}_{12}[\mathrm{~km}]$.

The selected properties were measured at an absolute humidity of $12 \%$. Compressive strength along the fibres ( $\mathrm{R}_{\mathrm{c} 12}$ ) was determined using an Instron 3382 machine. Modulus of elasticity under static bending $\left(\mathrm{Eg}_{12}\right)$ and static bending strength $\left(\operatorname{Rg}_{12}\right)$ were measured using an Instron 3369 instrument.

\section{Results and discussion}

The highest mean density was obtained for trees from stand $10\left(537.30 \mathrm{~kg} / \mathrm{m}^{3}\right)$, and the lowest for stand $16\left(479.45 \mathrm{~kg} / \mathrm{m}^{3}\right)$. The average density of Scots pine wood for all of the studied material at Rogów Forest Experimental Station was $513.76 \mathrm{~kg} / \mathrm{m}^{3}$. The smallest density calculated for a single sample was $340.11 \mathrm{~kg} / \mathrm{m}^{3}$ (stand 16), and the largest was $782.97 \mathrm{~kg} / \mathrm{m}^{3}$ (stand 10).

The highest mean compressive strength $(\mathrm{Rc})$ was obtained for stand $5(45.45 \mathrm{MPa})$, and the lowest for stand 16 (40.14 MPa). For the whole of the studied material, the mean compressive strength along the fibres was $43.72 \mathrm{MPa}$, with values for individual samples ranging from a minimum of $20.33 \mathrm{MPa}$ (stand 2) to a maximum of $63.19 \mathrm{MPa}$ (stand 15).

The highest mean static bending strength $(\mathrm{Rg})$ was found for wood from stand $12(102.13 \mathrm{MPa})$, and the lowest for stand 16 (83.53 MPa). The mean for the whole of the studied material was 94.45 $\mathrm{MPa}$. The lowest value for an individual sample was $23.94 \mathrm{MPa}$ (stand 5), and the highest was 169.80 MPa (stand 12).

The highest mean modulus of elasticity under static bending (Eg) was obtained for wood from stand $12(9825 \mathrm{MPa})$, and the lowest for stand 16 (8433 MPa). For the whole of the studied material the mean value was $9291 \mathrm{MPa}$, and for individual samples the values of this parameter ranged from $3259 \mathrm{MPa}$ to $16,490 \mathrm{MPa}$, both extreme values occurring in stand 12 .

The highest mean value of the index of strength quality under compression along the fibres $(J R c)$ was determined for pine wood from stand $15(8.72 \mathrm{~km})$, and the lowest for stand $16(8.28 \mathrm{~km})$. For the whole of the studied material the mean value of this index was $8.42 \mathrm{~km}$, and values for individual samples ranged from $3.50 \mathrm{~km}$ (stand 10) to $10.48 \mathrm{~km}$ (stand 15).

The highest mean value for the index of strength quality under static bending (JRg) was obtained for wood from stand $12(19.15 \mathrm{~km})$, and the lowest from stand $16(17.20 \mathrm{~km})$. The mean value of this index for the whole of the studied material was $18.23 \mathrm{~km}$, and values for individual samples ranged from a minimum of $3.68 \mathrm{~km}$ (stand 10) to a maximum of $38.35 \mathrm{~km}$ (stand 5).

For the index of strength quality related to the modulus of elasticity under static bending (JEg), the highest mean value was obtained for wood from stand $12(1838.12 \mathrm{~km})$ and the lowest for stand $10(1722.19 \mathrm{~km})$. For the whole of the studied material the mean value was $1790.40 \mathrm{~km}$. Values of the index for individual samples ranged from $621.63 \mathrm{~km}$ (stand 7) to $3920.08 \mathrm{~km}$ (stand 5).

Pine in Poland plays an important role, both in the formation of forests and in the economy. It is subject to extensive phenotypic variability [17], as a result of which multiple varieties, climatypes and ecotypes have been distinguished. Due to the widespread use of Scots pine timber and the importance of its physical and mechanical properties, it is beneficial to study pines of different origin in order to identify the most valuable stands.

The present study concerned trees of seven different origins grown on an experimental plot at Rogów Forest Experimental Station. The results made it possible to determine the technical quality of pine wood from different parent stands. The seed material originated from areas with different elevations, natural conditions, and lengths of growing season. The experimental stand was located in the same climate and soil conditions and the same habitat type (fresh mixed forest, LMśw).

Density is one of the most important physical properties of wood, and has an impact on its other technical properties [18]. Statistically significant differences were found in the mean density values between the studied stands. From the geographical variability it is seen that a stand from southern Poland has lower wood density than a population from the lowland part of the country. 
Giertych [19] identified mountain populations of pine that were not suitable for cultivation in lowland Poland. The mean density was calculated to be $490 \mathrm{~kg} / \mathrm{m}^{3}$. The smallest value for an individual sample was $340.11 \mathrm{~kg} / \mathrm{m}^{3}$ (from stand 16), and the highest was $782.97 \mathrm{~kg} / \mathrm{m}^{3}$ (from stand 10). This property was found to be highly variable between samples. Wood density exhibits variation both between trees and within individual trees [20].

There was found to be high variability in mean values of compressive strength among the seven populations. Wood is stronger in a direction parallel to the fibres than across the fibres. This results from the anisotropic structure of wood [21]. The mean compressive strength along the fibres measured for Scots pine wood was 43.5 MPa. Reported values for European species range from 30 to $70 \mathrm{MPa}$ [22]. The Nowy Targ population (stand 16) in southern Poland is evaluated as average [23, $24,25]$. In terms of variation in breast height diameter, average height, sum of cross-sectional areas at breast height, and log volume, trees originating from that area achieved the worst results in a study of 23 populations [26].

Significant differences were found between the studied pine populations in the case of static bending strength. This is the maximum value of stress attained by a tested wood sample. Typical values of bending strength range from 80 to $100 \mathrm{MPa}$ [20]. The lowest bending strength of a single sample was $23.94 \mathrm{MPa}$, for a sample from stand 5 (130 m a.s.l.), and the highest was seven times greater, at $169.80 \mathrm{MPa}$, for a sample from stand 12. According to Krzysik [8] the average static bending strength of knot-free pine wood is $100 \mathrm{MPa}$. Wagenführ [27] gives a range for Pinus sylvestris L. from 35 to $206 \mathrm{MPa}$.

Modulus of elasticity denotes a type of stiffness of wood under various loads. Values of the modulus of elasticity ranged from 6900 to $20100 \mathrm{MPa}$. A high value of MOE indicates a good wood resistance [28]. The mean value of this index is $9015 \mathrm{MPa}$ [29], 10080 MPa [30]. The highest stand density MOE mean is increasing [31].

The results given above on the variation in technical quality in Scots pine with seven different origins confirm the existence of differences within this species in Poland. Polish tree populations present differences in the quality of wood [32]. Trees originating from a mountain population were not successful in lowland areas.

Analysis of the results obtained in this study shows that the differences between the studied populations are statistically significant. This means that it is possible to select the best areas of origin of Scots pine to achieve the optimum technical quality of the wood for specific applications.

\section{Conclusions}

It was shown that the technical quality of the wood of Scots pine (Pinus sylvestris L.) growing in the environmental conditions of central Poland, defined on the basis of physical and mechanical properties, exhibits significant differences depending on its genetic origin.

Origin was shown to have a significant influence on wood density, compressive strength, static bending strength, and modulus of elasticity under static bending.

The highest mean density was found for trees originating from stand $10\left(533 \mathrm{~kg} / \mathrm{m}^{3}\right)$ and stand $5\left(531 \mathrm{~kg} / \mathrm{m}^{3}\right)$. The highest values of compressive strength were obtained for trees originating from stands 5 and $12(45 \mathrm{MPa})$, and the highest static bending strength and modulus of elasticity under static bending were obtained for trees originating from stand $12(102 \mathrm{MPa}$ and $9868 \mathrm{MPa}$ respectively).

The lowest values of the studied properties were obtained for trees originating from stand 16 (Nowy Targ).

The results indicate that it ought to be possible to select the origin of planting material so as to obtain the highest quality and productivity of future stands.

Author Contributions: Conceptualization, P.K., W.B and H.L.; methodology, P.K. and H.L.; software, P.K., H.L. and E.K..; validation, H.L.; formal analysis, E.K. and H.L.; investigation, E.K.; resources, E.K.; E.K.; writing - original draft preparation, H.L.; writing - review and editing, H.L.

Funding: This research received no external funding. 
Acknowledgments: The paper presents the wood obtained from Department of Forest Silviculture, Institute of Forest Sciences, Warsaw University of Life Sciences.

Conflicts of Interest: The authors declare no conflict of interest

\section{References}

1. BDL. Available online: http://www.bdl.lasy.gov.pl/portal/ (accessed on 27.10.2020).

2. Andrzejczyk, T.; Żybura, H. Sosna zwyczajna. Odnawianie naturalne $i$ alternatywne metody hodowli, PWRiL: Warszawa, Poland, 2012.

3. Ilmurzyński, E.; Włóczewski, T. Hodowla lasu, PWRiL: Warszawa, Poland, 2003.

4. Paschalis, P. Zmienność jakości technicznej drewna sosny pospolitej we wschodniej części Polski. Sylwan 1980, 124 (1), 29-44.

5. Kamiński, E.; Głowacki, S.; Paschalis, P. Badania wpływu zróżnicowanego obiegu żywicowania na wybrane właściwości drewna, Dokumentacja naukowa w Inst. Użyt. Lasu i Inż. Leśn: Warszawa, Poland, 1976.

6. Witkowska, J.; Lachowicz, H. Analiza zmienności gęstości umownej drewna sosny zwyczajnej (Pinus sylvestris L.) wzdłuż wysokości pnia w zależności od wybranych czynników. Przegląd Papierniczy 2012, 68 (9), 573-578.

7. Józefaciuk, J.; Laurow, Z. Zmienność niektórych cech makroskopowych drewna sosny zwyczajnej (Pinus sylvestris L.) na tle typów pokrojowych. Prace IBL 1974, 466, 26.

8. Krzysik, F. Nauka o drewnie, PWN: Warszawa, Poland, 1978.

9. Wodzicki, T.J. Natural factors affecting wood structure. Wood Science and Technology 2001, 35, 5-26.

10. Danusevičius, J. Use of introductions provenances to increase genetic diversity in local Scots pine populations. Biologija 2001, 1, 59-61.

11. Tomczak, A.; Pazdrowski, W.; Jelonek, T.; Grzywiński, W. Jakość drewna sosny zwyczajnej (Pinus sylvestris L.) Część I. Charakterystyka wybranych cech i właściwości wpływających na jego jakość. Sylwan 2009, 153 (6), 363-372.

12. PN-77/D-04227. Drewno. Ogólne wytyczne pobierania i przygotowania próbek; Polski Komitet Normalizacyjny: Warszawa, Poland, 1977.

13. PN-77/D-04101. Drewno. Oznaczanie gęstości; Polski Komitet Normalizacyjny: Warszawa, Poland, 1977.

14. PN-78/D-04102. Drewno. Oznaczanie wytrzymałości na ściskanie wzdłuż włókien; Polski Komitet Normalizacyjny: Warszawa, Poland, 1978.

15. PN-77/D-04103. Drewno. Oznaczanie wytrzymatości na zginanie statyczne; Polski Komitet Normalizacyjny: Warszawa, Poland, 1977.

16. PN-63/D-04117. Fizyczne i mechaniczne własności drewna. Oznaczanie współczynnika sprężystości przy zginaniu statycznym; Polski Komitet Normalizacyjny: Warszawa, Poland, 1963.

17. Hebda, A.; Wójkiewicz, B.; Wachowiak, W. Genetic characteristics of Scots pine in Poland and reference populations based on nuclear and chloroplast microsatellite markers. Silva 2017, Volume 51(2), 1-17.

18. Tomczak, A.; Jelonek, T.; Zoń, L. Porównanie wybranych właściwości fizycznych drewna młodocianego i dojrzałego sosny zwyczajnej (Pinus sylvestris L.) z drzewostanów rębnych. Sylwan 2010, 154 (12), 809-817.

19. Giertych, M. Zmienność proweniencyjna sosny zwyczajnej (Pinus sylvestris L.) w Polsce. Sylwan 1997, 8, 5-20.

20. Tomczak, A.; Jelonek, T. Gęstość drewna z bielastej części przekroju poprzecznego sosny zwyczajnej (Pinus sylvestris L.) pochodzącej z wybranych drzewostanów północno-zachodniej Polski. Forestry Letters 2014, 107, 5-9.

21. Kozakiewicz, P. Fizyka drewna w teorii i zadaniach, Wydawnictwo SGGW: Warszawa, Poland, 2012.

22. Kokociński, W. Drewno - pomiary właściwości fizycznych i mechanicznych,, Wydawnictwo AR: Poznań, Poland, 2004.

23. Kowaczyk, J.; Matras, J.; Żybura, H.; Sabor, J.; Barzdajn, W. Zmienność sosny pospolitej i hodowlana wartość jej proweniencji. Prace IBL 2000, 7, 164.

24. Kowalczyk, J.; Matras, J. Badania porównawcze populacyjnej i rodowej zmienności cech hodowlanych wybranych pochodzeń sosny zwyczajnej (Pinus sylvestris L.). Prace IBL 2006,1-245.

25. Gawron, L. Zmienność cech wzrostowych i jakościowych krajowych pochodzeń sosny zwyczajnej (Pinus sylvestris L.) Rozprawa doktorska, SGGW: Warszawa, Poland, 2014.

26. Barzdajn, W. Zmienność cech taksacyjnych sosny zwyczajnej (Pinus sylvestris L.) polskich pochodzeń w doświadczeniu proweniencyjnym z 1985 roku w Nadleśnictwie Zielonka. Sylwan 2006, 1, 8-19.

27. Wagenführ, R. Holzatlas,VEB Fachbuchverlag: Leipzig, Niemcy, 2007.

28. Liang, S-Q; Fu, F. Comparative study on three dynamic modulus of elasticity and static modulus of elasticity for Lodgepole pine lumber. Journal of Forestry Research 2007, 18 (4), 309-312. 
29. Hassan, K. T. S.; Horáček, P.; Tippner, J. Evaluation of Stiffness and Strength of Scots Pine Wood Using Resonance Frequency and Ultrasonic Techniques. BioRes. 2013, 8(2), 1634-1645.

30. Wood-database. Available online: https://www.wood-database.com (accessed on 27.10.2020).

31. Šilinskas, B.; Varnagirytė-Kabašinskienè, I.; Aleinikovas, M.; Beniušienė, L.; Aleinikovienė, J.; Škėma, M. Scots Pine and Norway Spruce Wood Properties at Sites with Different Stand Densities. Forests 2020, 11(5), 587.

32. Jakubowski, M.; Jelonek, T.; Tomczak, A. Compressive strength parallel to grain of Scots pine wood of wind- damaged and undamaged trees. Sylwan 2014, 158 (10), 787-794.

(C) 2020 by the authors; licensee MDPI, Basel, Switzerland. This article is an open access article distributed under the terms and conditions of the Creative Commons Attribution (CC-BY) license (http://creativecommons.org/licenses/by/4.0/). 